DOI https://doi.org/10.36059/978-966-397-113-1/47-64

\title{
MODERN AND HISTORICAL ASPECT OF THE INTERNATIONAL SECURITY OF THE STATE
}

\section{Bortnyak K. V.}

\section{INTRODUCTION}

Radical changes are taking place in the world and international law must change with them. Sovereign states still predominate and power remains the decisive element in the prevailing international order. International organizations still have to operate within their mandates and are under the sway of powerful states or voting majorities. And yet, there is room for structural change in the content and procedures of international law of the future, which must become an international law of security and protection with the United Nations indispensably in the forefront.

The fundamental aim of the text below is to deal with the concept and models of global security as one of the crucial topics of global politics studies. We have to keep in mind that a term and notion of security usually implies a kind of sense of protection and safety from different possible harms coming from "outside". Therefore, it can be generally acceptable and understandable that the states want to protect their own territories by expanding great resources in making their territorial safe. Security topics are of very different kind, ranging from the causes of conflict between states to deterioration in the global climate or women's rights in global politics. The question of Security Studies as an academic discipline within the scope of Global Politics has been the subject of much debate and one of the most prosperous ways to deal with global security is firstly to analyze different standpoints which are existing within the research discipline. The article, in one word, will try to provide the readers with a basic approaches in the academic field of Security Studies with some necessary personal remarks by the author.

\section{International law on security and protection}

In the third edition of The Charter of the United Nations: A Commentary, edited by Bruno Simma and others, the authors refer to the report of the former Secretary General Kofi Annan «In Larger Freedom: Towards Development, Security and Human Rights for All», 
noting that «the threats to peace and security in the twenty-first century include not just international war and conflict, but civil violence, organized crime, terrorism and weapons of mass destruction. They also include poverty, deadly infectious disease, and environmental degradation since these can have equally catastrophic consequences. All of these threats can cause death or lessen life chances on a large scale. All of them can undermine States as the basic unit of the international system» ${ }^{1}$.

The term «international security», in turn, they continue, requires «a transformation of international relations so that every State is assured that peace will not be broken, or at least that any breach of the peace will be limited in its impact. International security implies the right of every State to take advantage of any relevant security system, while also implying the legal obligations of every State to support such systems». The General Assembly, the authors further noted, «has stated that national and international security has become increasingly interrelated, which accordingly makes it necessary for States to approach international security in a comprehensive and cooperative manner».

The authors commented: «Traditionally, the concept of international security was perceived as primarily a problem of State security. Within recent years, however, an additional concept has emerged-that of human security, acknowledging that threats cannot only come from States and non-State actors, hut can also exist to the security of both States and the people».

They proceeded to point out that «International security can he promoted and achieved through various policies or measures, two of which are referred to in para 1 [of Article 1 of the Charter], namely measures of collective security and adjustment or settlement of international disputes.... International peace and security may $\mathrm{Be}$ endangered not only by acts of aggression, but also by any other threat to the peace» ${ }^{2}$.

What do the changing threats to international security signify for the future of international law and order? Nick Butler of the Policy Institute at King's College London explored these issues in "Action on Climate Change Is Self-defence Not Altruism», published in the Financial Times on 20 October 2015. He reported that, in the middle of October that year, at the École Militaire in Paris, military and civilian leaders debated

\footnotetext{
${ }^{1}$ As cited in Bruno Simma and others, eds., The Charter of the United Nations: A Commentary vol. I., 3d ed.(Oxford, Oxford University Press, 2017), p. 111-112.

2 As cited in Bruno Simma and others, eds., The Charter of the United Nations: A Commentary vol. I., 3d ed.(Oxford, Oxford University Press, 2017), p. 111-112.
} 
the risks and the defence and security implications of climate change at a seminar organized jointly by the French Senate and the Defence Ministry. Many of the risks were well-known-such as the possibility of desertification in particular regions, or water shortages leading to inadequate harvests and a lack of food supplies, and on the other hand, the prospect of floods or sudden surges in temperature; and the risk of diseases and epidemics spread by dirty water.

Climate «change», the article commented, sounded too mild a description and implied a gradual, linear shift over decades to a temperature $2^{\circ} \mathrm{C}$ higher than we are used to. The more likely reality, however, is climate disruption-erratic shifts in one direction or another. These raised the need for what the French call «green defence». The changing climate would drive even more people to migrate. Epidemics can spread rapidly in an age of global travel and trade. "In these circumstances it is hard to see how national and European security can he preserved without active intervention to deal with the problems at source. That means that European and possibly other countries will have to put people on the ground, and invest seriously in a process of development that helps to manage each of the risks and encourages the local population to stay instead of migrating». The French, Butler added, «are right to see the challenges associated with climate change as issues not just of energy policy and environmental protection but also as major defence and security challenges $\rangle^{3}$.

A month before Nick Butler's article on «green defence» was published, Martin Rees, the British Astronomer Royal, wrote an opinion piece entitled «Scientists and Politicians Alike Must Rally to Protect Life on Earth» for the Financial Times. The author warned: «Heat stress will most hurt those without air conditioning, crop failure will most affect those who already struggle to afford food, extreme weather events will most endanger those whose homes are fragile... Climate change is aggravating a collapse in biodiversity that could eventually he comparable to the five mass extinction events in Earth's history. We are destroying the hook of life before we have read it....To design wise policies, we need all the efforts of scientists, economists and technologists, and the best knowledge that the 21st century can offer. But to implement them successfully, we need the full commitment of political leaders and the full support of the voting public» ${ }^{4}$.

\footnotetext{
${ }^{3}$ Nick Butler, «Action on climate change is self-defence not altruism», Financial Times, 20 October 2015.

${ }^{4}$ Nick Butler, «Action on climate change is self-defence not altruism», Financial Times, 20 October 2015.
} 
On 2 February 2011, United Nations Secretary-General Ban Ki-moon delivered the fourth Cyril Foster lecture at Oxford University on the topic, «Human Protection and the 21st Century United Nations». He noted that «the founders of the United Nations understood that sovereignty confers responsibility, a responsibility to ensure protection of human beings from want, from war, and from repression. When that responsibility is not discharged, the international community is morally obliged to consider its duty to act in the service of human protection».

«The task of human protection», he acknowledged, «is neither simple nor easy. We don't always succeed. But we must keep trying to make a difference. That is our individual and collective responsibility. People like myself, as Secretary-General, and the leaders of the world have a moral and political responsibility to protect populations.» He continued: «The challenges facing us have changed, but our core responsibility to maintain international peace and security has not. Slowly but surely, sometimes by trial and error, we have learned to use the instruments available under the Charter in new ways, adapting to evolving circumstances. Through this evolution, the need to operationalize a concept of human protection has emerged.» «Undoubtedly», the Secretary-General acknowledged, «the UN needs to perform its protection duties more effectively....The best form of protection is prevention. Prevention saves lives as well as resources» ${ }^{5}$.

«Beyond the immediate protection agenda», he continued, «the United Nations was addressing the 'creeping vulnerabilities'. They also put populations at risk and weaken societies, and also plant the seeds of violence and conflict: water scarcity, food insecurity, corruption, transnational crimes, the effects of climate change. Often, this impact of climate change, water scarcity, has become the source of conflict, regional conflict, very serious regional conflict. So it is not surprising that these human security issues are finding their way onto our peacebuilding agenda, and specifically that ofthe Peacebuilding Commission».

«The UN», he acknowledged, «recognizes that human protection stands at the centre of both its purposes and principles».

The United Nations will have to change its approaches dramatically if it is to rise to the challenges of international protection. This will require great daring. In his acclaimed book, World Order, Henry Kissinger observed that «the idea that ... countries will identify violations of peace identically and be prepared to act in common against them is

\footnotetext{
${ }^{5}$ Ban Ki-moon, Secretary-General of the United Nations, "Human protection and the 21 st century United Nations", Cyril Foster Lecture at Oxford University, Oxford, United Kingdom, 2 February 2018. Available from http://www.un.org/sg/selected-speeches/statement_full.asp?statID=1064.
} 
belied by the experience of history.... Collective security has repeatedly revealed itself to be unworkable in situations that most seriously threaten international peace and security». He asked the question, "Were the rules and principles themselves the international order, or were they a scaffolding on top of geopolitical structure capable of-indeed requiringmore sophisticated management?».

Kissinger did not factor into his thinking the evolving challenges of international security and of human protection. The contemporary and future threats to international security and the challenges of international protection are such that even the mighty powers will have to recognize that United Nations action is necessary to save humanity and its habitat.

We shall need to turn to the United Nations as a system of public order, as advocated by the late Ian Brownlie: «The design of the United Nations constitutes a comprehensive public order system. In spite of the weakness involved in multilateral decision-making, the assumption is that the Organization has a monopoly on the use of force, and a primary responsibility for enforcement action to deal with breaches of the peace, threats to the peace or acts of aggression. Individual Member States have the exceptional right of individual or collective self-defence. In the case of regional organizations the power of enforcement action is in certain conditions delegated by the Security Council to the organizations concerned.

Enforcement action may involve the use of force on behalf of the community against a State. However, the practice has evolved of authorizing peacekeeping operations which are contingent upon the consent of the State whose territory is the site of the operations. In recent history the roles of peacekeeping and enforcement action have on occasion become confused, with unfortunate results.»)

We shall need to transform international law into a law of international security and protection.

The foundations of a new international law of security and protection are already in place. They consist of:

- The competences of the Security Council under Chapter 7 of the United Nations Charter: the Security Council must transform itself into the world's executive authority.

- The competences of the United Nations SecretaryGeneral under Article 99 of the Charter: the SecretaryGeneral must increasingly make submissions, including legal submissions, to the Security Council under 
Article 99 of the Charter and invite it to issue mandatory orders under Chapter 7 of the Charter.

- The recommendatory competences of the United Nations General Assembly combined with the process of the formation of international customary law: the Secretary-General must use his Annual Reports to the General Assembly to draw its attention to threats to human security and to indicate policies and recommendations that can, through widespread consensus, crystallize into norms of international customary law.

- The interpretative role of the International Court of Justice to clarify the role of the law in meeting the circumstances of contemporary society: the Security Council and the General Assembly should use their competences to submit requests to the International Court of Justice for Advisory Opinions on the duties of States to cooperate for the security and protection of humanity and its habitat.

There is also room for: security advisories by heads of United Nations agencies; protection alerts by the United Nations High Commissioner for Human Rights; security and protection actions by regional organizations; the urgent need for progressive development of international law in key areas has also been identified by scholars and practitioners. In his recent book, An Unfinished Foundation: The United Nations and Global Environmental Governance, Ken Conca calls upon the international community to urgently: find an explicit human right to a safe and healthy environment; acknowledge an environmental responsibility to protect; infuse the law-and-development approach with stronger peaceand rights practice; find a legitimate (and clearly limited) environmental role for the United Nations Security Council; exploit opportunities for environmental peacebuilding; reconceive and strengthen what it means for the United Nations to make a "system-wide" response on environmental problems ${ }^{6}$.

\section{International Systems of States and Global Security Models}

The conception of international systems of states is crucial as explanatory mechanism of both global politics and global security models. However, in order to understand international systems of states firstly the very notion of a system itself has to be clarified and defined. In this context, it can be said that "a system is an assemblage of units, objects, or parts united by some form of regular interaction". Any system is

\footnotetext{
${ }^{6}$ Ken Conca, An Unfinished Foundation: The United Nations and Global Environmental Governance (Oxford, Oxford University Press, 2015), p. 14.
} 
necessarily constructed of different members on micro and macro levels which are interacting between themselves from horizontal and vertical perspectives. The member units of a system are of different size, capacity, potentials, wealth, might and therefore of different positions regarding the decision making procedure and especially power ${ }^{7}$.

For the reason that member units of a system are constantly interacting with each other either from horizontal or vertical perspectives, it is quite naturally that in the case of a change in one unit the reactions to such change are expected by other units. The most expressed examples are arms race, seeking for balance of power, making political-military blocs with other units or even in the most drastic cases, committing aggression on the member unit. Any system with its member units has a tendency to regulate the relations between them and to try to respond by different means if those relations are changed at the expense of the hegemonic unit(s) of the system. It can exist at the same time two or more systems which are separated from each other by regulated boundaries, but different systems very often collaborate across the boundaries, for instance, in the areas of economy, knowledge or technology exchange as it was the case during the Cold War era (1949-1989). Finally, one system can break down for any reason what means that necessarily changes within the system were not achieved in order to save it (for instance, the case of the Warsaw Pact in 1990-1991). Subsequently, in stead of the old system a new system can emerged or the member units of the old system can be simply absorbed by another one as it happened, for example, with majority of the Central and South-East European states after the Cold War.

It is very difficult to fix the exact date when global system of international relations (IR) and therefore global security models started to work for the very reason that the process of globalization occurred over many centuries. However, the modern European system of IR can be traced back up to the time after the 1648 Westphalian Peace Treaty, while the process of globalization of international systems of inter-states relations started to work from the first half of the 19th century.

International systems of inter-states relations and global security became after the WWII investigated as academic subjects within the framework of World Systems Theory (WST) which recognizes that the states are historically playing the fundamental role in IR and they will do that in the future as well as but the systems of relations of (nation)-states

\footnotetext{
${ }^{7}$ Karen A. Mingst, Essentials of International Relations, Third edition, New York-London: W. W. Norton \& Company, 2014, 81 .
} 
have to be understood and put in the context of global unity rather than conflicts based on realizations of different national interests. What the theoreticians of WST suggest is that the most meaningful system of global security has to be based on world-system but not on nation-states system. Therefore, they believe that international cooperation and order will replace international conflicts and anarchy. However, behind WST is basically hidden a system of Capitalist World-Economy (CWE) which is advocating ideology of globalization as a new form of the Western global imperialism based on the international division of labour. Thus, according to CWE, the whole world is divided into three labour and economic zones: the core-states (the Western developed mature economies); the periphery-states(mainly ex-colonies from Africa with still underdeveloped economies); and the semi-periphery states (mainly EastEuropean ex-socialist states and Middle-East oil-rich states with rising economies and growing infrastructure). The essence of WST/CWE is that a globalization has to function in full benefit of the core-states which are fully exploiting the periphery-states with a semi-periphery states as a buffer between core and periphery segments of the world economy which are partially exploited by the core-states (by financial and economic means). In one word, WST/CWE is trying to legitimate existence and functioning of global Western capitalism and its exploitation of the rest of the world by promulgation of globalization ideology. However, the liberal ideology of globalization is advocating in reality the global process of (pervasive) American Westernization from all points of view - from cultural, economic or political to the issues of values, tradition and customs ${ }^{8}$.

Historically, there were three fundamental types of international systems or relations between the states as the crucial actors in global politics even today: independent; hegemonic and imperial.

The Independent State System (ISS) is composed by the states as political actors and entities which each of them claim to be independent that means both autonomous and sovereign. The fundamental feature of such state, at least from the very theoretical point of view, is that it has right and possibility to make its own foreign and domestic policies out of any influence or dependence from the outside. The ISS presupposes that the state territory and its citizens are under full control and governance by the central state authority and that the state borders are inviolable from

\footnotetext{
715 .

${ }^{8}$ Jeffrey Haynes, Peter Hough, Shahin Malik, Lloyd Pettiford, World Politics, New York: Routledge, 2013,
} 
outside. In other words, any outside actor is not eligible to interfere into domestic affairs of the state which can be governed only by one "legitimate" authority that is internationally recognized as such. An independent state has to be and autonomous that means (as it meant at the time of ancient Greeks where the term comes) that the legitimate state authorities are adopting their own law and organizing the state activities, political and other types of life of the society according to it but not according to the imposed law, rules or values from the outside. States had to be equally treated and understood in regards to their claims to independence, autonomy and sovereignty regardless to the very practical fact that not all of them are of the same power, capabilities and might ${ }^{9}$.

The Hegemonic State System (HSS) is based on an idea of a hegemon and hegemony imposed by a hegemon in IR what means that one or more states (or other actors in politics) dominate the system of IR or/and regional or global politics. A hegemon is fixing the standards, values and the „rules of the game“ and having direct influence on the politics of the system's members like, for instance, the US in the NATO's bloc.

There are three possible types of HSS in global politics: unipolar (or Single) hegemony, when a single state is dominating as it was the case with the US immediately after the WWII; bipolar (or Dual) hegemony, when two dominant states exist in global politics as it was a case during the time of the Cold War (the USA and the USSR); multipolar (or Collective) hegemony, when several or even many states dominate international relations like during the time after the Vienna Congress in 1815 (Russia, Austria, Great Britain, France and Prussia).

In practice, in any of these three HSS, lesser powerful actors may interact their powers, but they have to get a permission by the hegemon for such action. In HSS, usually domestic affairs of the states are left untouched by the hegemon, while their foreign affairs are strictly under the hegemonic control.

The third type of IR, the Imperial State System (ImSS), existed from the ancient time (Assyria, Persia, Macedonia, Rome) and has been dominant in Europe, North Africa and Asia in the Middle Ages (the Frankish, Holy Roman, Byzantine, Ottoman or Habsburg empires). The essence of empire as a system is that it is composed by separate societal, ethnic, national, linguistic or/and confessional parts which are associated

\footnotetext{
${ }^{9}$ Cynthia Weber, Simulating Sovereignty: Intervention, the State, and Symbolic Interchange, Cambridge, UK: Cambridge University Press, 1994.
} 
by regular interaction. However, within such multi-structural imperial framework it is a regular practice that one unit dominate over others by imposing over the rest its own political supremacy. The rest of the framework units have to accept such reality either by force or by interest while a political supremacy by one (ruling) part can be accepted by the others either implicitly or explicitly. However, the question arises what is a difference between the Hegemonic and the Imperial State System as these two systems seems to be very similar if not even the same? Nevertheless, the fundamental difference is that a dominant unit of an empire is much more able to manage other subjects of the state system in comparison to HSS and especially to force them to work for the central authority (tax collection, recruiting people for the imperial army, appointing local political client leaders, etc.). The empires are usually created and enlarged by military conquest, but also they can be militarily destroyed from the outside or disappear due to the inner revolutions followed by civil wars.

Security dilemma is based on an idea that security is a goal for which states struggle and compete between themselves. In principle, the states have to look to their own protection especially in an "anarchical" world system in which does not exist any supranational authority (like the UNO or OEBS, for instance) to be capable to impose and/or to ensure regional or global order of IR. In practice, traditionally, the states in order to achieve their security goals were striving for more and more power for the reason to escape the impact of the power and foreign policy of other states especially of the neighbours as the European history clearly shows. However, such practice in turn makes the other states or other actors in IR to feel themselves more insecure and therefore it encourages them to be prepared for the worst scenario (conflict, aggression, war). As any state cannot ever feel entirely secure, the security competition among the states is endless process that is resulting in constant power rising. In other words, security dilemma provokes a policy to firm security of a (nation)state which has a direct effect of threatening other states or actors in IR and, thereby, provoking power (usually military) counter-actions. This endless process is in fact decreasing security for all states especially if we know that in many cases offensive (imperialistic) foreign policy is justified by national arming by "defensive" weapons (the case of the US, for instance).

Global security as a concept has to be essentially founded on the idea of human (individual and group) security. However, IR in practice are 
based on the right to self-preservation of the states (i.e., of their political regimes and social elites in power). This idea is born by Englishman Thomas Hobbes (1588-1679) who argued that the right to selfpreservation is founded on a natural law, requiring at the same time a social harmony between the citizens and state authority. Therefore, global security has to be founded primarily on the concept of (a nation)state security as the states are natural form of political associations by the people and still are the fundamental actors in IR. The idea is that, presumably, both individual and civil rights of the citizen would be effectively secured only if the individual consented to the unchecked power of the state ruling elite. Therefore, we can say that a modern philosophy of state totalitarian regimes is de facto born by Th. Hobbes.

Based on Th. Hobbes' security philosophy, states will stress the necessity of social collectivisation for the protection of their security interests - it is how the concept of Collective Security (CS) was institutionalised as a mechanism that is used by the states in one bloc not to attack or proclaim the war to other states within the same bloc of coalition. The member states of the same bloc accept the practice to use their collective armed forces and other necessary capabilities in order to help and defend a fellow member state in the case of aggression from outside. Such "defensive" collective action has to continue until the time when "aggression" is reversed. The essence of such concept, therefore, is a claim that an ,unprovoked“, aggressive attack against any member of an organisation is going to be considered as an attack on all member states of that organisation. In practice, any really provoked attack of aggression can be easily claimed as „unprovoked“ as it happened, for instance, with the case of Pearl Harbour in 1941 as we know today that the US regime did everything to provoke „unprovoked“ Japanese action on December 7th. Nevertheless, while the concept of CS became the tool to count state aggression, it left very open question of how best to promote the individual or group (minority) security ${ }^{10}$.

It has to be clarified that the very idea of human security is not opposing concern of national (state) security - the requirement that state is in obligation to protect its own citizens from the aggression from the external world, i.e. by a foreign actor. The human security idea argues that the most important focus of security has to be put on individual not on state but the state has to protect all its citizens as the protection umbrella

\footnotetext{
${ }^{10}$ Martin Griffiths, Terry O’Callaghan, Steven C. Roach, International Relations: The Key Concepts, Second edition, London-New York: Routledge, Taylor \& Francis Group, 2008, 147.
} 
from the outside threat. This approach takes an individual-centred view of security that is a basis for national, regional and finally global security. In essence, protection of human (individual and group) rights is giving the main framework for the realization of the concept of human security that advocates "protection against threats to the lives and well-being of individuals in areas of basic need including freedom from violence by terrorists, criminals, or police, availability of food and water, a clean environment, energy security, and freedom from poverty and economic exploitation"11.

The chief purpose of collective security organization is to provide and maintain peaceful relations within the bloc which is composed by sovereign states but dominated by a hegemon. The concept of CS has declaratory as a main task to maintain peace between the key actors in IR that practically means the states, but in practice the real purpose of CS system is just to maintain peace and order among the members of the system, however not between the system and the rest of the world. The best example of CS system today is the NATO (North Atlantic Treaty Organization) which is not of any kind of global security bloc but rather only political-military alliance that is primarily serving the US national interests (global imperialism) across the globe. Nevertheless, the practical implementation of the concept is fluctuating between two models: traditional and more realistic model of Balance of Power and a new postCold War and more utopian model of World Government.

The idea of CS is for sure very attractive for the academics as it seeks to bring about important benefits of a "global government" but without altering the fundamental essence of traditional states system of anarchy. The concept of CS from global perspective, therefore, means a "system of international security under which all states agree to take joint action against states that attack". Anyway, formally, the concept of CS wants to apply a set of legally established mechanisms which are designed to prevent possible aggression by any state against any other state at least without the formal permission by the UNO. Different theorists explain on different ways by using different arguments the benefits or disadvantages of one of three possible global security models: Unipolar, Bipolar or Multipolar. Debates are basically going around the arguments which one of these three models is the most stable and above all most peaceful in comparison to all other models ${ }^{12}$.

\footnotetext{
${ }^{11}$ Richard W. Mansbach, Kirsten L. Taylor, Introduction to Global Politics, Second edition, London-New York: Routledge, 2015, 578.

${ }^{12}$ Peter Hough, Understanding Global Security, Second edition, London-New York: Routledge, $2018,2$.
} 
Those who advocate the Unipolar Security Model (USM) claim that this model gives the most security guarantees as in this case there is simply one power (state) to be in a position of a dominant actor in global politics having a role of a global hegemon or world policemen. It is a belief that world politics can be mostly peaceful if there is a single dominant state that is strong enough to enforce peace as a global hegemon. The hegemon is going to be so powerful that no any other global actor can challenge its superiority in world affairs and IR. This model of global security was adopted by the US administration immediately after the Cold War and mainly was advocated by Zbigniew Brzezinski who was trying to laid down academic foundations of the American hegemonic position in global politics which had primarily goal to destabilize, dismember and finally occupy Russia for the sake of free of charge exploitation of her natural resources according to the Kosovo pattern from June 1999 onward. If the US administration succeed in realization of such goal, the global geopolitical game over the Eurasian Heartland would be finally resolved in the favour of Washington.

The NATO was, is and going to be from the very beginning of its existence (est. 1949) the fundamental instrument of the US policy of global hegemony concept that is known also as Pax Americana. Up today, the NATO remains the most powerful military alliance in the world that was allegedly established "...to provide security for Western Europe, NATO became an unprecedented peacetime alliance with a permanent secretariat and a military headquarters that represents the US commitment to deter Soviet aggression". However, the very existence of the NATO after the dissolution of the Soviet Union clearly prove that the ultimate goal of its creation and functioning was not "to deter Soviet aggression" while its (only eastward) enlargement from 1999 onward indicates that in fact Russia was, is and going to be the chief object of the fundamental point of the NATO's policy of the US expansionism and global hegemony. The 1998-1999 Kosovo War, in which the NATO's forces became deeply engaged for the first time after its establishment in 1949, marks the beginning of the direct US policy of brutal and open gangsterism (at least) after the Cold War on the global level of IR and world politics ${ }^{13}$.

\footnotetext{
${ }^{13}$ Experiment Kosovo: Die Rückkehr des Kolonialismus, Wien: Promedia Druck- und Verlagsges. m.b.h., 2012).
} 
The USM is necessarily founded on an idea of hegemony in global politics. The word hegemonia comes from the ancient Greek language (as many other words used today by the Western academic world) with authentic means of "leadership". In IR, a notion of a "hegemon" is used as a synonym for "leader" or "leading state" within the system (bloc) composed by at least two or several states. However, the bloc member countries have to establish and maintain certain relations between themselves what practically means that one of member states became de facto a hegemon within the whole bloc concerning decision making policy and procedure (for example, the USA in the NATO, the USSR in the Warsaw Pact or Germany in the EU). A leadership or hegemony within the system implies certain degree of order, collective organization and above all hierarchy relationships between the members of a system. However, political hegemony in IR is not existing by itself as it is a phenomenon which exists within some interstate system, that is itself the product of specific historical, political, economic, ideological or other circumstances. All hegemonic states within the system enjoy "structural power" which permits the leader to occupy a central leading position in its own created and run system. All other member states are collaborators to the leading role of the hegemon expecting to get a proper reward for their service. On the other hand, a hegemon has to mobilize its own economic, financial, technical, political, human and other resources in order to perform a role of a leader and, therefore, this is why only some (rich) states have a real potential to be hegemons (like the USA in the NATO, for instance).

The USA is today the world's most powerful and imperialistic single state ever existed in history. Washington is after the WWII using the NATO as a justification of its global hegemonic designs and the American ability and willingness to resume a hegemonic role in the world are of the crucial importance for IR, world order and global security. In principle, majority of studies dealing with hegemony and imperialism point to the British $19^{\text {th }}$ century empire and the US empire after the WWII as two most successful hegemonic cases in world's political history. Both of these two empires formally justified their policy of global imperialism within the framework of the concept of USM.

Probably the most important disadvantage of USM is that a unipolar world with a strong global hegemon will all the time tempt either one or several powers to try to challenge the hegemon by different means. This is basically an endless game till the hegemon finally lost its position as such 
and the system of security became transformed into a new form based on a new security model. That is exactly what happened with the Roman Empire as one of examples of USM.

Nevertheless, in the unipolar system, a hegemon faces few constraints on its policy, determines rules of game in global politics and restricts the autonomous actions by others as it was exactly the case by the US as a "world policemen" at the time of the New World Order in 1990-2008. But on the other side, such hegemonic position and policy of terrorizing the rest of the world (or system) provokes self-defence reactions by others which finally results in the change in the distribution of power among the states (or actors) that can be a cause of war on larger scale of intensity and space. For the matter of comparison, the US hegemonic, Russophobic and barbaric global policy at the time of the post-Cold War New World Order can at the end cause a new world war with Russia (and probably China) as the Peloponnesian War (431-404 BC) were caused by the hegemonic policy of the Athens which provoked the fear and self-defence reaction by Sparta ${ }^{14}$.

The champions of the Bipolar Security Model (BSM), however, believe that a bipolarity of global politics could bring a long-time peace and world security instead of USM. In the case of BSM, the two crucial powers in the world are monitoring each other's behaviour on global arena and therefore removing a biggest part of the security uncertainty in world politics, international relations and foreign affairs associated with the possibility of the beginning of war between the Great Powers.

A Multipolar Security Model (MSM) looks like as the best option dealing with the prevention of war and protecting global security as a distribution of power is as much as "multi" there are lesser chances for outbreak of the war between the Great Powers. In essence, MSM can moderate hostility among the Great Powers as they are forced to create shifting alliances in which there are no permanent enemies. Nevertheless, for many researchers, MSM is in fact creating a dangerous uncertainty for the very reason as there is a bigger number of the Great Powers or other powerful actors in world politics.

\section{CONCLUSIONS}

How is the international community to proceed in this reconceptualizing of international law to meet the new challenges of

\footnotetext{
${ }^{14}$ Михаил Ростовцев, Историја старога света: Грчка и Рим, Нови Сад: Матица српска, 1990, 112-120; Thucydides, The Peloponnesian War, Indianapolis: Hackett Publishing Company, Inc., 1999.
} 
security and human protection? The place to start would be for the United Nations Security Council to hold an urgent debate on the need for a new international law of security and protection. An enlightened member of the Council could submit a concept paper and advocate such a debate.

The academic research field of Security Studies is of extreme complexity raging from the standpoint that these studies should have a narrow military focus as the fundamental security threat to the territorial integrity of states comes during times of conflict to the view that individuals are the final research object of the studies but not the states themselves. Therefore, many academics focus their research on global security basically on human emancipation which is usually understood as achieving wide scope of freedoms - both individual and group. They argue that academic discipline of Security Studies should focus on them but not on the security of the state.

Finally, there are many arguments over what the research and referent object of Security Studies has to be, whether military power is fundamental for state security, who is going to be mainly responsible for providing security or what the studies as academic field have to consider as its research subject matter and focus. The fundamental aim of this article was to present the main route through the (mine) field of Security Studies as an academic research discipline.

\section{SUMMARY}

A Ukrainian begins the first cut on a Kh-22 air-to-surface missile during elimination activities at an air base in Ozernoye, Ukraine. The weapon was eliminated under the Cooperative Threat Reduction program implemented by the Defense Threat Reduction Agency. International security, also called global security, refers to the amalgamation of measures taken by states and international organizations, such as the United Nations, European Union, and others, to ensure mutual survival and safety. These measures include military action and diplomatic agreements such as treaties and conventions. International and national security are invariably linked. International security is national security or state security in the global arena.

With the end of World War II, a new subject of academic study focusing on international security emerged. It began as an independent field of study, but was absorbed as a sub-field of international relations. Since it took hold in the 1950s, the study of international security has 
been at the heart of international relations studies. It covers labels like «security studies», «strategic studies», «peace studies», and others.

The meaning of «security» is often treated as a common sense term that can be understood by «unacknowledged consensus». The content of international security has expanded over the years. Today it covers a variety of interconnected issues in the world that affect survival. It ranges from the traditional or conventional modes of military power, the causes and consequences of war between states, economic strength, to ethnic, religious and ideological conflicts, trade and economic conflicts, energy supplies, science and technology, food, as well as threats to human security and the stability of states from environmental degradation, infectious diseases, climate change and the activities of non-state actors. The material used in the study has only the analysis of information resources.

\section{REFERENCES}

1. As cited in Bruno Simma and others, eds., The Charter of the United Nations: A Commentary vol. I., 3d ed.(Oxford, Oxford University Press, 2017), p. 111-112.

2. Nick Butler, «Action on climate change is self-defence not altruism», Financial Times, 20 October 2015.

3. Martin Rees, «Scientists and politicians alike must rally to protect life on Earth», Financial Times, 5 September 2015.

4. Ban Ki-moon, Secretary-General of the United Nations, "Human protection and the 21 st century United Nations", Cyril Foster Lecture at Oxford University, Oxford, United Kingdom, 2 February 2018. Available from http://www.un.org/sg/selected-speeches/statement_full.asp?statID= 1064.

5. Ken Conca, An Unfinished Foundation: The United Nations and Global Environmental Governance (Oxford, Oxford University Press, 2015), p. 14.

6. Karen A. Mingst, Essentials of International Relations, Third edition, New York-London: W. W. Norton \& Company, 2014, 81.

7. Jeffrey Haynes, Peter Hough, Shahin Malik, Lloyd Pettiford, World Politics, New York: Routledge, 2013, 715.

8. Cynthia Weber, Simulating Sovereignty: Intervention, the State, and Symbolic Interchange, Cambridge, UK: Cambridge University Press, 1994. 
9. Martin Griffiths, Terry O'Callaghan, Steven C. Roach, International Relations: The Key Concepts, Second edition, London-New York: Routledge, Taylor \& Francis Group, 2008, 147.

10. Richard W. Mansbach, Kirsten L. Taylor, Introduction to Global Politics, Second edition, London-New York: Routledge, 2015, 578.

11. Peter Hough, Understanding Global Security, Second edition, London-New York: Routledge, 2018, 2.

12. Experiment Kosovo: Die Rückkehr des Kolonialismus, Wien: Promedia Druck- und Verlagsges. m.b.h., 2012).

13. Михаил Ростовцев, Историја старога света: Грчка и Рим, Нови Сад: Матица српска, 1990, 112-120; Thucydides, The Peloponnesian War, Indianapolis: Hackett Publishing Company, Inc., 1999.

\section{Information about author: Bortnyak K. V.}

Candidate of Science of Law, Assistant Professor, Assistant Professor at the Department of Constitutional and International Law of the Educational and Humanitarian Institute of the V. I. Vernadsky Taurida National University 33, Ivan Kudria str., Kyiv, Ukraine 